\title{
UNA OBRA INÉDITA DE DIEGO LÓPEZ BUENO Y ALONSO VÁZQUEZ: EL RETABLO DE LA CAPILLA DE LA CONCEPCIÓN EN EL CONVENTO CASA GRANDE DE SAN FRANCISCO DE SEVILLA
}

\author{
AN UNPUBLISHED WORK BY DIEGO LÓPEZ BUENO \\ AND ALONSO VÁZQUEZ: THE ALTARPIECE OF THE \\ CONCEPTION CHAPEL AT THE SAINT FRANCIS \\ CONVENT IN SEVILLE
}

\section{Francisco Amores Martínez}

Asociación Provincial Sevillana de Cronistas e Investigadores Locales, Sevilla. España

ORCID: 0000-0001-6445-902X

famoresm@yahoo.es

En el presente trabajo damos a conocer una nueva obra realizada por el escultor y arquitecto Diego López Bueno y el pintor Alonso Vázquez en 1597: el retablo para la capilla de la Concepción en el convento de San Francisco de Sevilla, propiedad del mercader Sebastián Pérez, y las circunstancias del pleito a que dio lugar su ejecución, en el cual intervinieron otros artistas de la época.

Palabras clave: Sevilla; convento de San Francisco; siglo XVI; Diego López Bueno; Alonso Vázquez.

We present in this paper a new work made by the sculptor and architect Diego López Bueno and the painter Alonso Vázquez in 1597: the altarpiece for the Conception Chapel at the Saint Francis Convent in Seville, owned by merchant Sebastián Pérez, and the lawsuit that led to its execution, in wich other artists of the time intervened.

Keywords: Seville; Saint Francis Convent; $16^{\text {th }}$ century; Diego López Bueno; Alonso Vázquez.

La figura de Diego López Bueno ha sido puesta en valor en nuestros días como uno de los principales arquitectos sevillanos del periodo manierista gracias 
a la obra que en esta faceta artística llevó a cabo durante el primer tercio del siglo XVII hasta su fallecimiento acaecido en 1632. No obstante, hay que señalar que desde que comenzó su andadura profesional en torno a 1588 junto a Juan Bautista Vázquez el Mozo, y durante los años siguientes, su dedicación principal fue la traza y ensamblaje de retablos, con las correspondientes labores de escultura vinculadas a aquellas obras lignarias. En este ámbito se ha achacado a López Bueno un estilo sincrético que aportó pocas novedades, bebiendo inicialmente de la fuente del purismo herreriano de Vázquez el Viejo, para evolucionar más tarde hacia un manierismo romanista que cultivaron también los discípulos de este último artífice, entre los que debe destacarse la maestría de Jerónimo Hernández, el citado Vázquez el Mozo, Andrés de Ocampo y Juan de Oviedo y de la Bandera. La vida de nuestro artista se desenvolvió en un ambiente culto, y en directa colaboración con la mayor parte de los otros escultores mencionados, y más tarde con otros como Martínez Montañés, así como con pintores como Alonso Vázquez, Francisco Pacheco o Juan de Uceda ${ }^{1}$. Por su parte, el citado Alonso Vázquez fue el pintor más valorado en Sevilla en la última década del siglo XVI, ciudad a la que había llegado poco antes de 1590 y en la que hasta su marcha a México en 1603, donde falleció ${ }^{2}$, desarrollaría una ingente labor en lo relativo a la policromía de retablos y esculturas, y en menor medida a la pintura de caballete, aunque era esto último lo que más le gustaba y donde alcanzaría altas cotas de calidad, cultivando un estilo puramente manierista ${ }^{3}$. En ambas facetas fue muy elogiado por sus contemporáneos, como fue el caso de su colega Francisco Pacheco $^{4}$, aunque en otros momentos llegaría a mantener agrias controversias con otros artífices de su propio gremio, como fue el caso de la que se suscitó a propósito de las pinturas del claustro del convento de San Francisco ${ }^{5}$. Se da la circunstancia de que, en aquellos años de tránsito entre los siglos XVI y XVII, Vázquez colaboró asiduamente con López Bueno, desde sus primeros trabajos conjuntos en el retablo de la capilla de Pedro López de Retana en la iglesia del mencionado convento de San Francisco de Sevilla (1599) o el mayor del convento trinitario de Santas Justa y Rufina (1601-1602), obras ambas no conservadas, hasta el retablo mayor del hospital de las Cinco Llagas $(1602)^{6}$ y el del Tránsito de San Hermenegildo en el hospital del Cardenal (1603), que es la última obra de Vázquez

${ }^{1}$ López Martínez, 1928a: 27-28 y 128-129; 1928b: 229-230; 1932: 64-65 y 199-233; 1953: s. p. Palomero Páramo, 1983: 434-470. Arenillas Torrejón, 1990: 219-232. Pleguezuelo Hernández, 1994. Luque Teruel, 2004: 438-440. Halcón, 2009: 89-102.

2 Palomero Páramo, 2005: 169-202.

3 López Martínez, 1932: 21-22, 65-66 y 208-215. Valdivieso González, 1992: 97-102. Moreno Galindo, 2014: 112-125.

${ }^{4}$ Pacheco, 1990: 445-447, 458, 485 y 511.

5 Palomero Páramo, 2018: 229-242.

${ }^{6}$ Serrera Contreras, 1991: 139-184. 
realizada en Sevilla. Pues bien, por nuestra parte añadimos ahora al catálogo de ambos artistas una obra inédita, desgraciadamente desaparecida, que contrataron en común Vázquez y López Bueno en 1597: el retablo para una nueva capilla que pocos meses antes había construido el mercader Sebastián Pérez en la portería del convento casa grande de San Francisco de Sevilla bajo la advocación de la Inmaculada Concepción. La escritura de concierto que se conserva en el archivo de la hermandad de la Vera $\mathrm{Cruz}^{7}$ nos permite llevar a cabo una reconstrucción bastante aproximada de aquel retablo, pero además el pleito posterior a que dio lugar su ejecución hará también posible conocer jugosos detalles relativos a la primera etapa profesional de López Bueno y a su relación con otros artistas del momento. Documentos que ponen de manifiesto, por otra parte, una aparente bisoñez del maestro ensamblador en aquellos años iniciales de su trayectoria laboral como tracista o proyectista de retablos.

Comenzaremos señalando que el comitente del retablo que nos ocupa, Sebastián Pérez, había nacido en la ciudad de Cádiz en el primer tercio del siglo XVI, fruto del matrimonio entre Diego Pérez de Fuensalida y María Gómez, con quienes se había trasladado posteriormente a Sevilla. En la capital andaluza contrajo matrimonio con Catalina Zapata, estableciéndose en una casa ubicada junto a la puerta de Triana, en la calle de Cantarranas, collación de Santa María Magdalena, la misma en la que tenía su taller Diego López Bueno. En la documentación conservada se alude a don Sebastián simplemente como "mercader", suponiendo por nuestra parte que se dedicó fundamentalmente al comercio con las Indias. En este sentido, contamos con indicios de que una de sus actividades pudo ser el comercio de esclavos, pues en su testamento alude al envío a Nueva España de algunas personas de raza negra. Curiosamente, algunos de los señores que por aquellos mismos años -desde 1594- realizaban gestiones para construir en el mismo ámbito del compás de San Francisco la capilla de la hermandad de los portugueses eran también señalados comerciantes esclavistas ${ }^{8}$, con toda seguridad conocidos de Pérez. Pues bien, uno de los elementos que servían entonces a la adinerada burguesía hispalense para manifestar públicamente su estatus era la fundación de una capilla familiar con fines funerarios en algún templo prestigioso de la ciudad, y si ello se hacía en uno de los más importantes y mejor situados, como lo era la casa grande de los franciscanos, ubicada junto al cabildo secular y a pocos pasos de la catedral, el prestigio de la familia en cuestión se veía notablemente incrementado. Teniendo en cuenta todo ello, Sebastián Pérez tuvo a bien solicitar a los frailes de San Francisco un espacio que existía junto la portería del convento en su lado izquierdo, la cual se abría por una parte a la plaza hoy llamada de San Francisco y por otra, a la calle de Tintores, actual de Joaquín

\footnotetext{
7 Archivo de la Hermandad de la Vera Cruz de Sevilla (AHVCS), caja 088.

${ }^{8}$ Gutiérrez Núñez/Hernández González, 2018: 162-165.
} 
Guichot ${ }^{9}$. Una vez obtenida la oportuna licencia, Pérez hizo construir entre 1596 y 1597 una capilla que puso bajo la advocación de la Inmaculada Concepción de la Virgen María, devoción entonces omnipresente en todos los espacios sagrados de la ciudad, y en la propia iglesia del convento. Parece que era esta la primera capilla que se construía en el compás, pues las que más tarde existieron allí, la de la hermandad de las Benditas Ánimas y San Onofre -único resto arquitectónico que ha subsistido del conjunto monástico- y la de San Antonio de los Portugueses, se edificaron ya entrado el siglo XVII. Es por ello que en los documentos que ahora analizamos se alude a ella no como una capilla más de la portería, sino como "la" capilla de la portería. Al tratarse de una capilla familiar no debió ser de grandes dimensiones. Según testimonios de los siglos XVIII y XIX tenía planta rectangular, y en nuestra opinión su traza cabe atribuirla al arquitecto Asensio de Maeda, por ser este quien se encargó por los mismos años de trazar la planta y alzado de la citada y vecina capilla de los portugueses, y otras obras del mismo convento. Algo que demuestra la elevada posición social que había llegado a alcanzar Sebastián Pérez es que obtuvo del Capítulo de la Basílica de San Juan de Letrán numerosas gracias e indulgencias a favor de su capilla, plasmadas en un documento expedido en Roma con fecha de 3 de octubre de 1598, y que fue recibido en Sevilla por el racionero de la catedral Bartolomé Olalla de Rojas el día 6 de diciembre de aquel mismo año. El documento en cuestión se halla hoy custodiado en el archivo de la hermandad de la Vera Cruz de Sevilla ${ }^{10}$, tratándose de un bello pergamino miniado de $68 \times 50 \mathrm{~cm}$, orlado a color con las imágenes de la Inmaculada Concepción, San Juan Bautista y San Juan Evangelista, además de los escudos del papa Clemente VIII y del monarca español Felipe II (Figura 1).

Para la nueva capilla encargó Sebastián Pérez un retablo al maestro entallador, ensamblador y escultor Diego López Bueno y al pintor de imaginería Alonso Vázquez, que se encargaría de las labores de policromía, estofado y esgrafiado. La escritura de concierto entre ambos artistas y el comitente se firmó en Sevilla el día 29 de junio de 1597, y por ella se obligaban los mencionados artífices a labrar un retablo en madera de borne, según la traza que para ello habían dibujado, por un precio de 780 ducados -la mitad para cada uno de ellos-, comprometiéndose a tenerlo acabado en un plazo de seis meses en lo relativo a las labores de talla y escultura, y un mes más en lo que respecta al dorado y la policromía. Según se deduce de las condiciones acordadas, el retablo se configuraba en base a un banco en el que Vázquez pintaría los retratos de Sebastián Pérez y su esposa Catalina Zapata, un cuerpo dividido en tres calles por columnas estriadas, presumiblemente de orden dórico aunque ello no se especifica en la escritura, y finalmente

9 González de León, 1844: 57-58. Morales Martínez, 1981: 41. Del Castillo y Utrilla, 1988: 93-94. La autora sin embargo sitúa erróneamente la fundación de esta capilla a comienzos del siglo XVI.

${ }^{10}$ AHVCS, Bulas y privilegios, documento D016. 
un cuerpo superior o ático. El programa iconográfico propuesto a los artistas por el comitente tenía un carácter eminentemente mariano y franciscano, con algunos elementos reservados para la familia propietaria de la capilla, como los retratos que debía pintar Alonso Vázquez en el banco, y el relieve del santo que daba nombre al comitente. Así, en la hornacina central se colocaría una imagen de bulto redondo de la Purísima Concepción, de "tamaño natural", y en el intradós del arco, tallados en relieve, los "atributos" de la Virgen, es decir, los símbolos de la letanía lauretana. En los nichos laterales se dispondrían otras dos imágenes de poco más de un metro de altura representando a los santos de la orden seráfica San Bernardino de Siena y Santa Clara de Asís, también de bulto redondo y concebidas como la de la Inmaculada para poder sacarlas en procesión. Sobre las dos hornacinas laterales se situaban unos "cuadros" con sendos relieves de San Diego de Alcalá y de San Sebastián, tallados "con muy buena gracia y arte". Por su parte, el ático estaría ocupado en su centro por un altorrelieve representando a Dios Padre, y en los extremos por dos esculturas de bulto redondo alegóricas de sendas virtudes teologales, que aunque no se especifica debían ser la Fe y la Esperanza.

El proyecto no difería mucho de lo que era común entre los tracistas sevillanos de finales del siglo XVI, y era muy similar al de otros retablos que había ejecutado López Bueno por aquellos años, como es el caso del de la Concepción para la iglesia parroquial de Moguer, contratado en aquellos mismos meses de 1597 aunque concluido en 1606, desgraciadamente desaparecido también ${ }^{11}$. Las esculturas del retablo de Sebastián Pérez debían presentar el estilo cultivado entonces por López Bueno, es decir, un manierismo heredado principalmente de Jerónimo Hernández, con incipientes atisbos naturalistas, tal como se aprecia en algunas obras de nuestro artista algo posteriores, como las imágenes del retablo del capitán García de Barrionuevo en la iglesia sevillana de Santiago, entre ellas la principal de la Inmaculada Concepción. Por su parte, podemos evocar las características del trabajo ejecutado por Alonso Vázquez recurriendo a otras escrituras de concierto de la misma época, en las que el pintor muestra su preferencia por el uso del oro bruñido esgrafiado con colores finos para los distintos elementos del retablo, mientras que las esculturas exentas las estofaba con todo detalle a punta de pincel y utilizando las encarnaciones a pulimento. Todo ello podemos contemplarlo en una de las escasas obras que se conservan de la mano de Vázquez, cual es la policromía del retablo de la familia Caballero de Cabrera en la iglesia parroquial de San Andrés de Sevilla, realizada en 1598 de una manera primorosa ${ }^{12}$, tanto en la imagen de talla de la Purísima, obra anterior de Gaspar Núñez Delgado, como en los atributos marianos que decoran el arcosolio que la cobija y el resto de pinturas que recubren por completo la obra, donde por otra parte

\footnotetext{
${ }^{11}$ López Martínez, 1932: 183-184.
}

12 Moreno Galindo, 2014: 124-125. 
encontramos muchos elementos iconográficos comunes con el retablo de Sebastián Pérez, al cual nos remite directamente este retablo de San Andrés.

Los artífices cumplieron razonablemente con el plazo señalado en el contrato, pero no así con el diseño que habían presentado para el retablo de la capilla de la Concepción, pues introdujeron en él ciertas modificaciones, aumentando las dimensiones de la obra tanto en altura como en anchura, con la intención de que se adaptase mejor a las del testero de la capilla, algo que aunque como ellos alegarían después suponía una mejora en el resultado final porque además se mantenían las proporciones, lo cierto es que sorprende que no lo hubieran tenido en cuenta desde el principio. Esta reforma del proyecto inicial, que supuso además la supresión de la cruz que estaba previsto que rematase el conjunto, motivaría el descontento del comitente con el resultado final de la obra, lo que daría lugar a un pleito ${ }^{13}$. Efectivamente, con fecha 1 de abril de 1598, Sebastián Pérez se dirigió a la Real Audiencia manifestando que "el retablo que han hecho y puesto en la capilla no es conforme a la traza y condiciones de la escritura que dello me tienen echo la cual en presento y en dicha escritura hay condición que en estando acabado se pongan y nombren un oficial del arte por cada uno de nos para que vean si han hecho y acabado el dicho retablo conforme a la dicha escritura y traza", y tomando la iniciativa designaba por su parte a Andrés de Ocampo, maestro escultor, para que llevase a cabo dicho reconocimiento. Dos días más tarde hacía lo propio Diego López Bueno, en su nombre y en el de Alonso Vázquez, quienes designaron para tal menester a Juan de Oviedo. Seguidamente se justificaba sobre lo sucedido, alegando que había hecho más de lo que estaba obligado, "porque en lugar de una cruz que tenía de tener por remate del retablo subí el retablo hasta la bóveda aviendo como avía cumplido con poner una cruz de una bara que quedase vazío todo lo demás del testero e pues con él mejora la obra justo es que se me pague la dha mejora". Es decir, no solo negaba haber incumplido el contrato, sino que solicitaba que se le pagase la demasía que por cuenta propia había ejecutado. En este punto debemos señalar que la relación de López Bueno y Alonso Vázquez con los dos colegas a quienes se encomendó la valoración del retablo ya era entonces bastante estrecha pero lo sería sobre todo en los años siguientes. En cuanto al arquitecto, escultor e ingeniero Juan de Oviedo y de la Bandera, debemos recordar que aquel mismo año de 1598 dirigió la construcción en la catedral del célebre túmulo funerario en honor de Felipe $\mathrm{II}^{14}$, empresa en la que colaboraron en sus respectivas disciplinas tanto López Bueno como Alonso Vázquez. Por su parte, la colaboración de este pintor con el escultor Andrés de Ocampo se remontaba al año 1593, cuando trabajaron juntos en varios retablos de la iglesia conventual de Santa Paula de Sevilla ${ }^{15}$.

\footnotetext{
13 AHVCS, caja 088.

14 Pérez Escolano, 1977: 34-38.

15 López Martínez, 1932: 208-214.
} 
El día 10 de abril los mencionados maestros Andrés de Ocampo y Juan de Oviedo se presentaron en la capilla de la Concepción para examinar el retablo, y seguidamente evacuaron el informe que se les había solicitado, señalando lo que sigue: "hallamos que conforme al pitipié de la traça que era obligado el dicho diego lopes a hazer de quatro varas y media y una ochaba de alto el dicho retablo y con esto avía cumplido y en el anchura hallamos está obligado a hazer tres varas y media y no cabales porque todas las condisiones de la dicha escritura se refieren a que se guarde la medida y proporsión de la traça y hallamos que no embargante que él no tenía obligación a hazer más que la cantidad referida de alto y fecho él se alargó a hazer dos palmos y medio más en el altura hasta que llegó con el frontispicio a genchir hasta la bóveda de la dicha Capilla. Y en el ancho aumentó y cresió tres quartas antes más que menos". Decían que gracias a esta modificación se había conseguido ejecutar una obra bien proporcionada, y valoraban lo añadido en 52 ducados y medio. "Y en lo que toca a una condisión que dize que se ha obligado a hazer los atrybutos de nuestra Señora de medio reliebe dezimos que en la traça no le obliga a hazer más que siete atrybutos y en la obra hallamos quince de pintura con muy buena orden mejor que en la traça donde antes hallamos aber en esta mejoría". De ello se deduce que estos elementos que López Bueno pensaba inicialmente tallar en bajorrelieve se hicieron finalmente pintados directamente sobre tabla por parte de Alonso Vázquez, aumentando su número de siete a quince. Más adelante, y antes de estampar por segunda vez sus respectivas rúbricas, añadieron los maestros como última recomendación a las justicias que López Bueno debía poner en el último cuerpo los remates que faltaban, adaptándolos al tamaño disponible, si bien le eximían de colocar la cruz que también figuraba en la traza, porque no cabía.

Sebastián Pérez no aceptó las conclusiones de los peritos, los cuales, a pesar de certificar que no se habían cumplido todas las condiciones de la escritura, manifestaban que las proporciones del retablo eran correctas, pero que en su opinión esto lo hacían únicamente por la amistad que les unía a sus autores. Y así, una semana más tarde, volvió a acudir a los oficiales de la Audiencia para, en primer lugar, solicitar que López Bueno presentase la traza del retablo, algo que al parecer se negó a hacer en un primer momento, y, más tarde, solicitando que la justicia ejecutase a los artistas obligándoles a devolver los 780 ducados que ya habían recibido en paga por la obra, que el promotor no valoraba más que en 400 . Finalizaba su alegato pidiendo que se mandase a los artistas retirar el retablo de la capilla. A la vista de esta reclamación, los jueces solicitaron de nuevo la comparecencia de los artífices, que presentaron sus alegaciones el día 20 de abril, solicitando se denegase la ejecución y por el contrario se condenase a Pérez a pagarle a cada uno 52 ducados y medio, valor en el que habían tasado la obra añadida los peritos. Por primera vez entró en escena personalmente el pintor Alonso Vázquez, declarando que "lo que yo me obligué a pintar fue lo que estuviese hecho de talla y escultura por diego Lopez entallador y escultor y pues yo pinté y doré y estofé 
todo lo que estuvo hecho de talla y escultura por el dho diego lopez". Exigía por ello que se le dieran los mismos 52 ducados que al tallista, reiterando la satisfacción que el retablo había suscitado inicialmente al comitente, y que por ello le había permitido cobrar sus honorarios en el banco de Pedro de la Torre Espinosa. Finalmente, Vázquez pedía que se nombrase por las partes a dos pintores de imaginería para que viesen la labor de pintura realizada por él y tasasen el valor de la demasía ejecutada, si bien esta última solicitud no fue tenida en cuenta. Por su parte, Diego López Bueno añadía en su escrito presentado el mismo día que el demandante recibió el retablo y le satisfizo la obra, y que luego se asentó en la capilla en su presencia y con la asistencia del padre guardián del convento y de otros frailes, así como que él había cumplido lo pactado y que lo que había añadido a los atributos marianos había sido para mejorar y perfeccionar la obra. Concluye afirmando que el parecer que habían dado los escultores y arquitectos Andrés de Ocampo y Juan de Oviedo era justo, porque "los que lo dieron son maestros mui diestros y sabios que hacen obras de gran perfección y porque dexaron de tasar tres partes que an visto que ay en el retablo que declararon además de lo que yo era obligado y no se tasó aquí y no es justo que se me dexe de pagar pues aquí es travajo y ocupación de mi persona". Oído el parecer de las dos partes, finalmente el alcalde de la Real Audiencia de Sevilla José del Castillo proveyó un auto en el que sentenciaba que la demanda presentada por Sebastián Pérez no era procedente, y aconsejando a los artistas que si lo estimaban oportuno reclamasen por otra vía el pago de las demasías que habían realizado en el retablo, con la condición de que Diego López colocase primero los remates que le faltaban en el último cuerpo, tal y como habían determinado los peritos. Una decisión en cierto modo salomónica que sin embargo las dos partes volvieron a recurrir en apelación, empecinándose López Bueno que solo haría los remates que faltaban si se le pagaba la demasía ejecutada, pero finalmente todos tuvieron que acatar la sentencia, que fue confirmada en los mismos términos por la misma Audiencia el día 4 de junio de 1598.

En los primeros meses del año 1615, el pintor de imaginería Amaro Vázquez volvió a dorar y estofar las tres imágenes del retablo de la Concepción, la de la Inmaculada y las de San Bernardino y Santa Clara, suponemos que porque habrían sufrido algún deterioro importante a causa de su repetido uso procesional. Se da la circunstancia de que Vázquez era por entonces prioste de la cofradía de la Vera Cruz, propietaria de la capilla ${ }^{16}$. El caso es que, finalizada esta labor, y como era costumbre, el administrador del patronato fundado por Sebastián Pérez, Francisco de Collantes, solicitó el parecer de dos peritos, también pintores de imaginería, para que tasasen la obra realizada por Amaro Vázquez, que resultaron ser Juan de Uceda y Diego de Salcedo, los cuales con fecha 30 de marzo de

16 Álvarez Moro, 1998: 85. 
1615 evacuaron un informe en el que manifestaban la excelencia del dorado y estofado a punta de pincel en las tres figuras, valorando la mayor en 600 reales y las dos menores en 300 reales cada una, lo que suponía un total de 1.200 que la hermandad de la Vera Cruz pagó al artista con fecha de 26 de abril de aquel mismo año. Por lo demás, nos consta que Amaro Vázquez realizó más tarde otras obras junto a Diego López Bueno, concretamente un retablo dedicado a la Inmaculada Concepción para la catedral de Comayagua en Honduras, obra de $1620^{17}$, y otro dedicado a la Virgen del Rosario en la iglesia parroquial de El Pedroso ${ }^{18}$, contratado en 1628. Y en cuanto a Juan de Uceda, sabemos que también trabajó con el citado escultor, haciéndose cargo inicialmente de los trabajos contratados junto a este por Alonso Vázquez, de quien se piensa que Uceda pudo ser discípulo ${ }^{19}$.

Sebastián Pérez falleció en Sevilla el día 27 de julio de 1608, siendo ya viudo desde hacía nueve años. Había otorgado testamento un año antes ante el escribano Pedro Vázquez de Miranda ${ }^{20}$. Por la citada postrera voluntad, abierta en presencia de fray Mateo de Recalde, uno de los religiosos más importantes del convento de San Francisco, don Sebastián dejaba a la hermandad de la Vera Cruz como adjudicataria de su capilla cuando él falleciese, prohibiendo expresamente que la misma cediese su propiedad a ninguna otra persona ni institución en tiempo alguno y accediendo a que se enterrasen en ella las personas que la hermandad tuviera a bien, pagando por cada una al convento de San Francisco 50 ducados. Pérez era hermano de la Vera Cruz, y asimismo de la cofradía de las Benditas Ánimas establecida en el mismo cenobio y de la archicofradía Sacramental del Sagrario de la catedral. En el mismo testamento confirma y amplía la dotación de una capellanía que su esposa había fundado en su capilla propia en 1599, y de la cual la hermandad de la Vera Cruz era ya patrona y administradora desde el año 1600. Pérez instituyó por su parte una fiesta dedicada a la Inmaculada Concepción, que se debería celebrar en su festividad con procesión solemne desde su capilla a la iglesia del convento, donde tendría lugar una misa mayor con sermón, llevando en andas las imágenes de la Purísima, San Bernardino y Santa Clara que se veneraban en el retablo de su capilla. Dejaba la quinta parte de sus rentas para la redención de cautivos, preferentemente andaluces y vascongados, y con el resto instituía una obra pía para dotar a doncellas pobres, con preferencia por las hijas de los hermanos de la Vera Cruz. Encomienda a esta hermandad la organización de la procesión del ocho de diciembre, en la que además de sus cofrades con la cera propia, debían participar los frailes franciscanos y las doncellas que hubiesen sido agraciadas con dotes durante ese año, ataviadas con sayas blancas y "con sus mantos de anascote y con sus escapularios de tafetán azul con

\footnotetext{
17 Palomero Páramo, 1983: 455.

18 Delgado Aboza, 2009: 257-273.

19 Valdivieso González, 1992: 141.

${ }^{20}$ AHVCS, caja 088.
} 
unos escudos de la limpia concepción de nuestra señora conforme a los doce escapularios que yo tengo en mi casa".

Las últimas noticias fehacientes que tenemos sobre el estado de la capilla de la Concepción se remontan al año 1706, cuando su propietaria, la hermandad de la Vera Cruz, cedió el "mero uso" de la misma a la congregación de Nuestra Señora de la Oliva y Santo Cristo del Perdón, que daba culto a sendas imágenes -la de la Virgen era al parecer una pintura- existentes en el mismo compás del convento de San Francisco. Su hermano mayor Fernando de Medinilla, junto a otros catorce cofrades de la Oliva, firmaron la correspondiente escritura el 10 de junio, y por parte de la Vera Cruz sus diputados José Antonio de Arteaga y Alonso Begines, abogados de la Real Audiencia ${ }^{21}$. El interés que tiene para nosotros este documento es que incluye un inventario de la capilla, que la describe de la siguiente manera: "Primeramente la rexa entera de fierro que haze dos Puertas. Un Retablo Dorado echura Antigua. La imagen de Nra Señora de la Purísima Concepción que está en dho Retablo. Dos echuras de san Bernardino de Siena y santa Clara. Una bara de fierro en dos mitades con las ebillas necesarias para el belo de Semana Santa. Una baranda de fierro con tres perillas de bronce con su puerta y serroxo. Y una campanilla de bronce cascada cuios vienes a de bolber a entregar dcha Congregación quando dexe el uso de dcha capilla”. Cincuenta años más tarde, las hermandad de la Vera Cruz consideró, en junta de gobierno celebrada el día 15 de marzo de $1756^{22}$, retirar a la congregación o hermandad de la Oliva el uso de la capilla de la Concepción, considerando que los pocos hermanos que de ella quedaban habían dejado de cumplir las condiciones que se habían establecido en cuanto al cuidado de la misma y su aseo, alegando por parte de dichos congregados que la llave de la capilla la tenían los porteros del convento, los cuales "querían permaneciese en la reja la cortina todo lo más del día hechada y que servía para guardar diferentes omenajes y esteras. Por cuia razón avían retirado la Cortina y que por esta causa se hallaba sin el aseo correspondiente", determinando la cofradía propietaria pedir la llave al padre guardián y de paso recordarle de quién era la propiedad. No conocemos el desenlace del asunto, pero se deduce que la pronta extinción de la mencionada congregación haría que la Vera Cruz volviese a hacerse cargo de su cuidado en las décadas siguientes. Se cree que la capilla debió desaparecer en el incendio que destruyó la mayor parte del convento de San Francisco el día 1 de noviembre del año 1810, que se atribuyó a los invasores franceses, y lo cierto es que si algún resto quedó de ella fue demolido treinta años más tarde para ampliar por ese lado el edificio de las casas capitulares y abrir la nueva

${ }^{21}$ Archivo Histórico Provincial de Sevilla (AHPSe), Protocolos notariales, legajo 14.649, oficio 21 , libro $1^{\circ}$ de 1706 , ff. 749-752.

${ }^{22}$ AHVCS, libro 6, Libro de acuerdos desde el 15 de enero de 1733 hasta $1^{\circ}$ de junio de 1757, f. 193. 
plaza que hoy existe ante ellas. Su antiguo retablo se da por perdido ${ }^{23}$, pues si su propietaria la hermandad de la Vera Cruz pudo apenas, en aquellos años funestos, salvar y conservar la parte más importante de su patrimonio, no es probable que pudiese hacer mucho para poner a resguardo el existente en la capilla de la portería, que por entonces era el más antiguo que poseía y por ello el que debía encontrarse en peor estado.

\section{APÉNDICE DOCUMENTAL}

29-6-1597, Sevilla.

Escritura de concierto de Diego López Bueno y Alonso Vázquez con el mercader Sebastián Pérez para ejecutar el retablo de la capilla de la Concepción en el convento de San Francisco de Sevilla.

AHVCS, caja 088.

"Sepan quantos esta carta vieren como yo alonso vazquez pintor de imagineria e yo diego lopez escultor vezinos de esta ciudad de sevilla juntamente de mancomun e cada uno de nos por si ynsolidun e por el todo rrenunciando como expresamente rrenunciamos a las leyes de duo rres devendi y el autentica presente de fideisoribus y el vebeficio de la divicion y execucion y las demás leyes e derechos de la mancomunidad como en ella se contiene somos y conocemos que somos convenidos e concertados con vos sevastian perez mercader vezino desta ciudad en la collacion de la madalena que sois presente en tal manera que seamos obligados por esta presente carta anvos devaxo de la dicha mancomunidad e cada uno ynsolidun nos obligamos de hazer e dar echo e acavado en toda perfeccion un retablo que para buestra capilla que teneis en el monestterio de san $\mathrm{fc}^{\circ}$ de esta ciudad el qual dho rretablo haremos de ensamblage talla y escultura y dorado y estofado y esgrafiado con dos rretratos de vos el dicho sevastian perez y de doña catalina vra muger todo ello conforme a la trassa e modelo que de nuestro acuerdo e vuestro esta fecho en una vitela pergamino firmada de nuestros nonbres y del vuestro y del presente escribano conforme a unas condiciones que tanbien estan fechas del nuestro acuerdo y de vuestro superior derecho quales es esta que se sigue

En nombre de dios amen estas son las condiciones por donde se tiene de hacer el rretablo del señor sevastian perez; primeramente es condizion que dicho rretablo tiene de hazerse por la trassa y condiciones que parecieren firmadas del señor sevastian perez y los maestros que hizieren dicho rretablo

Iten es condicion que este rretablo a de cer de la grandessa y tamaño que convenga y este vien para que zincha y ocupe todo el testero de la capilla donde tiene

${ }^{23}$ Fernández Rojas, 2009: 90. 
de estar y servir guardando siempre la proporción y modo que muestra la dha traza

Iten es condición que en la caxa principal de este rretablo se tiene de hazer una ymagen de la limpia concepcion tamaño como el natural figura rredonda de mui buena escultura con su buena peana acomodada de manera que se pueda llevar en procesion y asimismo en los nichos que estan a los lados de esta dicha caxa se tienen de hazer en cada uno un santo en el uno san bernardino y en el otro santa clara figuras rredondas de buena escultura con sus mui buenas peanas asimismo acomodados para poderlos llevar en procesion se tienen de hazer estas dos figuras de vara y media de alto cada una y en todo lo demas que lleva el dicho rretablo se tiene de hazer puntualmente como parece y esta trassado y dibuxado en la dha trassa planta y montea

Iten es condicion que en estando hecho y acavado del todo punto este rretablo lo tienen de ver dos maestros abiles y suficientes en tal menester y hombres de buenas conciencias nonbrados por las partes cada parte el suyo uno el señor sevastian perez y otro el maestro que hiciere el dicho rretablo los quales dichos maestros declaren con juramento que dicho rretablo lo esta hecho e acavado en toda perfeccion sin aver defeto ni falta en cossa ninguna y si esta conforme a la traça e condiciones que para ello estan hechas y para ello buena obra asi del escultura como de arquitetura y talla lo qual no siendo ansi que de ello sea boluntad o del señor sevastian perez quererlo recevir o no quererlo recevir

Iten es condicion que las colunas de este retablo tienen de ser estriadas de estrías de cal de arriba avaxo

Iten es condicion que toda la arquitetura y talla de este rretablo se tiene de hacer de madera de borne mui bien saçonada linpia e sana sin samago ninguno

Iten es condicion que la paga de dicho retablo a de ser en tres meses luego de presto para comenzar la dicha obra la una tercia parte de todo el dinero en que se concertare y en estando hecho la mitad del rretablo la otra tercia parte la ultima tercia parte en estando acavado del todo punto el dicho retablo

Iten es condicion que los quadros que estan ensima de los nichos de el uno tiene de ser un medio cuerpo de san sevastian de medio relieve y en el otro un medio cuerpo de san diego tanbien de medio relieve y los dos con muy vuena gracia y arte

Iten es condicion que el maestro que este rretablo hiciere a de ser obligado a acentarlo e ponerlo en su lugar de manera que quede muy firme y seguro y vien acondicionado

Iten es condicion que este rretablo se tiene de dar hecho e acavado del todo de madera talla y samblaje y escultura dentro de seis meses que se contaran desde el día de la fecha

Iten es condicion que el dios padre que esta dibuxado en la dicha traça tiene de cer de escultura de poco mas de medio relieve y de la manera que esta dibuxado en la trassa 
Iten es condicion que las virtudes que estan sentadas en el frontispicio tienen de cer figuras redondas de muy buena escultura con sus insinias que declaren que virtudes son

Iten es condicion que en los artecenos del arco e paflon de la caxa principal de este retablo se tienen de hacer de medio relieve los atributos de nuestra señora que en ellos enpiezen por la horden que en la dicha traça estan dibuxados o como mas convenga y este bien

Iten es condicion que si alguna cossa fuere menester hacer en el dicho retablo para que quede bien acavado a de cer obligado de lo hacer aunque aquí no vaya declarado no inobando esta nueva a mas de lo contenido y dibuxado en el dicho dibuxo

Iten es condicion que esta dicha obra a de cer hecha y acabada dentro de los dichos seis meses y asentado en la dicha capilla y si ansi no lo hiciere pueda escoxer a boluntad del dicho sevastian perez querello recevir y por lo que asi uviere recivido le pueda executar el dicho oficial que haga el dicho rretablo e todo lo demás que costare de lo que aquí va declarado me pueda executar por ello e por lo que uviere recivido con solo su simple juramento

Iten es condicion que se a de dar e pagar por el dicho rretablo trecientos e noventa ducados en reales pagados por sus tercias partes como esta dicho y declarado

E asimismo se a de dar este dicho rretablo e santos con todo lo que le perteneciere por dichos trecientos e noventa ducados en el dicho plazo

Y conforme a la dicha traça y a las dichas condiciones sin eceder de ello nos obligamos de hacer el dicho retablo luego e no alsar la mano del asta lo aver acavado y en lo que toca al ensamblaje y escultura del lo daremos acavado el dicho dia de la fecha de esta carta en seis meses cumplidos primero siguientes y en lo que toca a pintura e dorado y estofado y esgrafiado lo daremos hecho y acavado y asentado de hoy dia de la fecha de esta carta en siete meses cumplidos primeros siguientes por razón de todo lo qual abemos de aber e vos savastian perez nos aveis de pagar setecientos e ochenta ducados para cada uno de nos la mitad con lo que nos a de quedar e quedan a nuestro cargo el hacer e dar hecho el dicho rretablo sin que vos el dicho sevastian perez pagueis otra cossa alguna siendo como abremos de ser obligados de asentar el dicho rretablo en la dicha capilla a nuestra costa y que la dicha suma nos aveis de pagar en esta manera ducientos e sesenta ducados que monta el un tercio de la dicha suma que nos aveis pagado e nos abemos recivido en reales de contado de que nos damos por contentos e pagados a nuestra boluntad serca de lo qual renunciamos de leyes de la inumerata pecunia de prueba de la paga como en ella se contiene y otros ducientos e sesenta ducados del segundo tercio nos aveis de pagar y a quien nuestro poder uviere aquí en sevilla fecha la mitad de la dicha obra del dicho rretablo y la otra tercia parte restante estando hecho e acavado el dicho retablo y abiendo sentado en la dicha capilla conforme a la dicha traça e condiciones una paga en pos de otra y en esta manera nos obligamos de cumplir lo susodicho si ansi no lo hicieremos y cumplieremos 
consentimos e abemos por bien que vos sevastian perez o quien vuestro poder o causa uviere por sola autoridad y sin nos lo requerir e hacer saver ni alguno de nos podáis concertaros con otros maestros de los dichos nuestros artes de cada uno de nos que hagan e acaben el dicho rretablo de qualquier parte e por el precio que los puediere hallar e por todo lo demás que costare de los dichos setecientos e ochenta ducados e por todos los maravedís que uvieremos recivido e por todas las costas e daños que se siguieren nos podáis executar e cada uno de nos como por deuda liquida con solo vuestro juramento y declaracion o de quien vuestro poder uviere en que lo difirimos sin que sea necessario ninguna prueba ni averiguacion ni liquidacion ni testimonio que de derecho se requiera de que os rrelevamos e podáis pasar de este rremedio e rigor de der $^{\circ}$ e via executiva demandarnos por todo rrigor de derecho a que fagamos y asentemos el dicho rretablo por el horden que deseeis de lo uno e lo otro qualmas quisieres de el useis de los dichos rremedios juntos a la par o el cada uno de por si sin que nada os pare perjuicio e yo el dicho sevastian perez acepto esta escriptura e me obligo de pagar y cumplir lo que por ella es a mi cargo sin falta alguna y para el cumplimiento della ambas partes por lo que toca a cada una damos poder bastante a las justicias del rey nuestro señor para que por todo rrigor de derecho e via executiva y en otra manera nos executen y apremien a cada uno de nos y nuestros bienes a el cumplimiento e paga de lo que dicho es como por sentencia passada en cosa juzgada e rrenunciamos las leyes e derechos de nuestro favor y la general rrenunciacion e obligamos nuestras personas y bienes abidos e por aber fecha la carta en Sevilla en el oficio de mi el $\mathrm{scri}^{\mathrm{o}} \mathrm{pu}^{\mathrm{o}}$ y susoescriptos de que doy fe conosco y en el rregistro firmaron sus nonbres a veinte e nueve del mes de junio de mill e quinientos e noventa e siete años".

Fecha de recepción: 25 de septiembre de 2019

Fecha de aceptación: 13 de abril de 2020

\section{BIBLIOGRAFÍA}

Álvarez Moro, María Nieves Concepción (1998): Historia y arte en la hermandad de la Vera Cruz de Sevilla. Sevilla: Centro Asturiano en Sevilla.

Arenillas Torrejón, Juan Antonio (1990): “Diego López Bueno, arquitecto del Monasterio de Santa Paula de Sevilla (1615-1623)”. En: Archivo Español de Arte, 250, pp. 219-232.

Del Castillo y Utrilla, María José (1988): El convento de San Francisco Casa Grande de Sevilla. Sevilla: Diputación Provincial de Sevilla.

Delgado Aboza, Francisco Manuel (2009): "El retablo de la Virgen del Rosario de la parroquia de El Pedroso, obra inédita de Diego López Bueno y Amaro Vázquez". En: Archivo Hispalense, 279-281, pp. 257-273.

Fernández Rojas, Matilde (2009): Patrimonio artístico de los conventos masculinos desamortizados en Sevilla durante el siglo XIX: Trinitarios, Franciscanos, 
Mercedarios, Jerónimos, Cartujos, Mínimos, Obregones, Menores y Filipenses. Sevilla: Diputación Provincial de Sevilla.

González de León, Félix (1844): Noticia artística, histórica y curiosa de todos los edificios públicos, sagrados y profanos de esta Muy Noble, Muy Leal, Muy Heroica e Invicta Ciudad de Sevilla, y de muchas casas particulares. Sevilla: Imprenta de José Hidalgo, vol. II.

Gutiérrez Núñez, Francisco Javier/Hernández González, Salvador (2018): “Nuevas noticias en torno al origen de la Capilla de San Antonio de la nación portuguesa, del convento de San Francisco (Sevilla). 1594-1614”. En: Peláez del Rosal, Manuel (dir.): El franciscanismo hacia América y Oriente. Córdoba: Asociación Hispánica de Estudios Franciscanos, pp. 162-165.

Halcón, Fátima (2009): "Diego López Bueno, arquitecto de retablos: nuevas aportaciones a su obra". En: Laboratorio de Arte, 21, pp. 89-102.

López Martínez, Celestino (1928a): Retablos y esculturas de traza sevillana. Sevilla: Tipografía Rodríguez, Jiménez y Compañía.

_ (1928b): Arquitectos, escultores y pintores vecinos de Sevilla. Sevilla: Tipografía Rodríguez, Giménez y Compañía.

- (1932): Desde Martínez Montañés hasta Pedro Roldán. Sevilla: Tipografía Rodríguez, Giménez y Compañía.

_ (1953): "El escultor y arquitecto Diego López Bueno (1568?-1632)". En: Calvario, s. n., s. p.

Luque Teruel, Andrés (2004). "La influencia purista de Juan de Herrera y Juan Bautista Vázquez el Joven en los retablos de Diego López Bueno”. En: Cuadernos de arte e iconografía, 26, pp. 431-442.

Morales Martínez, Alfredo J. (1981): La obra renacentista del Ayuntamiento de Sevilla. Sevilla: Ayuntamiento de Sevilla.

Moreno Galindo, Concepción (2014): "Alonso Vázquez, el pintor desde la perspectiva de su obra polícroma". En: Atrio, 20, pp. 112-125.

Pacheco, Francisco (1990): Arte de la pintura. Madrid: Cátedra.

Palomero Páramo, Jesús M. (1983): El retablo sevillano del Renacimiento: análisis y evolución (1560-1629). Sevilla: Diputación Provincial de Sevilla.

- (2005): "Las últimas voluntades y el inventario de bienes del pintor Alonso Vázquez". En: Anales del Instituto de Investigaciones Estéticas, 86, pp. 169202.

(2018): "Los pintores sevillanos contra Alonso Vázquez por negarse a repartir los frescos del claustro de San Francisco: injurias, amenazas y atentados ¡A las armas!”. En: Gómez de Terreros Guardiola, Ma del Valle/Pérez-Prat Durbán, Luis (eds.): Las ruinas: concepto, tratamiento y conservación, pp. 229-242.

Pérez Escolano, Víctor (1977): Juan de Oviedo y de la Bandera. Sevilla: Diputación Provincial de Sevilla. 
Pleguezuelo Hernández, Alfonso (1994): Diego López Bueno: ensamblador, escultor y arquitecto. Sevilla: Diputación Provincial de Sevilla.

Serrera Contreras, Juan M. (1991): "Alonso Vázquez: el retablo mayor del Hospital de las Cinco Llagas)". En: Archivo Hispalense, 227, pp. 139-184.

Valdivieso González, Enrique (1992): Historia de la pintura sevillana. Sevilla: Guadalquivir.

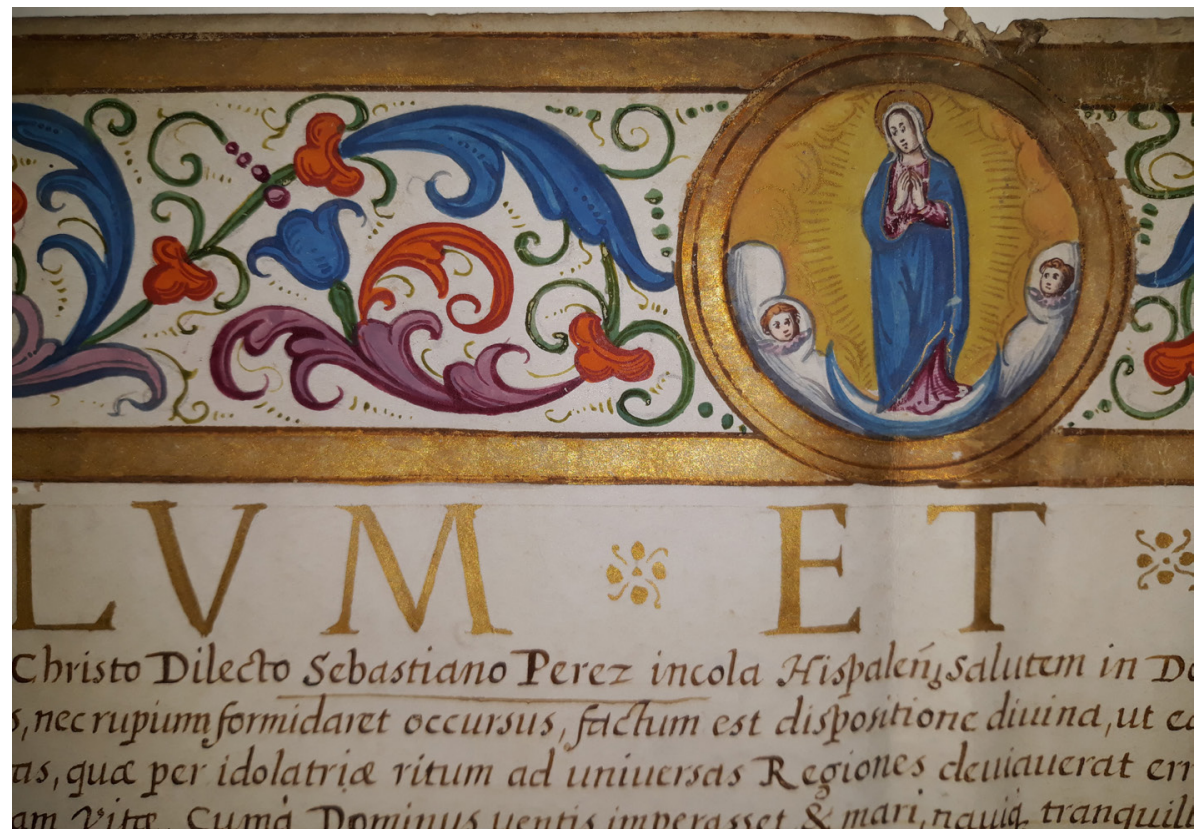

Figura 1. Talleres romanos, Carta de agregación de la capilla de la Concepción a la basílica de San Juan de Letrán (detalle), 1598, AHVCS, Bulas y privilegios, D0016.

Foto: Francisco Amores Martínez. 